\title{
Repercussions of institutional governance \\ changes on communication practices in the Afar National Regional State, Ethiopia
}

\author{
Olivia Pearson and Matthias Schmidt
}

Formal and informal institutions guide and shape communities and communication practices worldwide. Colonization, modernization and political transformation processes changed and questioned the role and relevance of informal institutions and strengthened the position of formal institutions. This paper looks at institutional governance transitions and the increasing presence of formal as opposed to informal clan based practices in the pastoralist lowlands of the Afar Region, Ethiopia, by analysing its impact on communication practices. Afar is governed by numerous multi-scale institutions; a complex network of governmental and traditional, formal and informal bodies at different scales. The region witnessed the devaluation of indigenous and traditional customs, which altered how and with whom pastoralists and agro-pastoralists communicate. The paper's case study shows that although residents now report their concerns to formal institutional representatives, traditional institutions are still functional. This change allows females to take a more active role in reporting concerns and communicating with authority figures. However, spatial disadvantages are present in this vast and sparsely populated region as those based further away from government representatives are disadvantaged. The relevance for a clear understanding of communication methods on the ground is stressed, in particular for implementing and disseminating programs and policies in this aid-dependent area.

\section{Introduction}

Formal and informal institutions, 'rights, duties, and obligations' (Searle, 2005: 11) shape relationships, and guide and limit lives worldwide. 'Institutions are the humanly devised constraints that structure political, economic and social interaction' (North, 1991: 97). Institutions help to form societal norms and structures by determining what is and is not acceptable and thus impact future actions (Newenham-Kahindi, 2015). The legal recognition of formal institutions, including documented laws and policies, is typically deficient in informal institutions that traditionally function through de facto means. This has led to the perception that informal institutions lack legitimacy, thereby potentially minimizing their power and influence. A good example is the critical interrelationship between formal, documented land rights and indigenous or traditional land rights, the latter being orally transmitted over generations and followed by various groups (Ensminger, 1997).

Institutions are not static and changes to an institution's 'value structure' (Bush, 1987: 1099) will alter institutional dynamics and practices, e.g., the introduction of new laws. Institutions must adapt to economic developments, technological innovations or changing external circumstances like climate change (Rodima-Taylor et al., 2012). People are managed through institutions (Kamoche et al., 2015) and adjustments of both formal and informal institutions are promoted as tools that can assist developmental endeavours in the Global South. Both formal and informal rural institutions can be useful to strengthen the adaptive capacities of local communities faced with change (Agrawal \& Perrin, 2009). Theories such as new institutional economics have been used to highlight the importance of formal and informal institutions for 'political and economic development' (Tamanaha, 2015: 89).

Across Africa, governments define how they will relate to, work with or exclude traditional structures (Hinz, 2007). In areas where traditional and informal institutions are characterized as weak, ineffective or irrelevant, formal institutions are introduced as a strategic tool that can empower developing communities. The introduction of formal institutions to replace traditional ones has been analysed in the Usangu Basin in Tanzania (Cleaver, 2002) and in south-eastern Nigeria, where the Igbo women lost their power when traditional institutions were replaced during British colonization (Van Allen, 1972). Informal institutions can also influence the creation and development of formal institutions (Casson et al., 2010). This was documented in Somaliland where, following 
the fall of Somalia in 1991, clans and their informal institutions helped to establish a new government (Renders, 2007).

Institutional transformations are driven by various elements and the analytical approaches to explore institutional change vary. Agrawal (2010) analyses local institutions and climate change adaptation practices by classifying historically observed adaptation practices. Forest governance is addressed by Schmidt (2012) through a political ecology approach and by Wakjira et al. (2013) with the theoretical concept of institutional adaption, while Beyene and Koch (2013) apply a multinomial regression model to study community forest institutions. Young (2010: 279) analyses the dynamics of institutional environmental and resource regimes through a framework derived from 'resilience, vulnerability, and adaptation in socio-ecological systems'. Donor interventions in Mongolia are analysed by Upton (2012) using a grounded theory approach, in Haller et al., 2013, new institutionalism was employed to examine the power and the political environment of pastoral commons in African floodplains, land privatization in Kenya's Samburu region is investigated through an analysis of exogenous and endogenous factors (Lesorogol, 2003) and Turner (2011) explores the new pastoral development paradigm found in various Africa's dryland property institutions.

Our paper addresses the current state of institutional governance in the Afar Regional State of Ethiopia. Historically this semi-arid lowland was governed by the traditional institutions of the Afar people who predominantly lived as pastoralists and practised animal husbandry, customising mobility and migration practices in order to live within their harsh environments (Harbeson, 1978). Those institutions, deeply entrenched in and supported by cultural practices of their inhabitants, include traditional laws, courts and conflict management methods, natural resource management and specific communication techniques (Sansculotte-Greenidge \& Fantaye, 2012; Reda, 2011a, b; Kassa, 2001). However, as traditional institutions are confronted by external forces, i.e., colonization, modernization or globalization, new formal and informal governance procedures that govern all aspects of society are created. Existing studies on transitioning institutions in lowland Ethiopia include those by Unruh (2005), who addresses how conflict resolution institutions are changing, and Kamara et al. (2004), who focus on pastoral resource management by addressing the emerging development pathways and their influential forces. Comprehensive research has not been conducted, however, on how institutional change is interpreted and understood at the community level and how this transition impacts communication practices. The objective of this paper is to examine how alterations in governance practices are currently modifying the roles of formal and informal institutions. Qualitative research was conducted with rural pastoralists and agro-pastoralists (those who derive an income from both animal husbandry and agriculture) as well as with government officials to shed light on their interpretation of the institutional changes in the region. We analyse how the introduced governance systems have been interpreted and utilized by rural Afar and document local perceptions of the clan's role in terms of governance and communication practices. Three indicators assess how the local population perceives the impact of institutional change: community leadership, communication patterns, and local awareness of policies and programs in the area. Our paper seeks to answer three key questions: (1) What are the repercussions of institutional governance changes on communication practices in Afar? (2) How do the Afar perceive their concerns and demands to be communicated and met? (3) What is the relevance for the implementation of development programs and policies? We began with an introduction to formal and informal institutions, followed by a description of the study area and methods. Traditional Afar institutions and the governance transitions in the area are summarized using primary data and supported by existing literature. The results precede the discussion which (i) presents an analysis of the data while comparing results to those derived from similar areas and (ii) provides recommendations based on our results. The paper ends with concluding remarks.

\section{Study area and methods}

\section{Study area}

The Afar National Regional State is located in Ethiopia's north eastern lowlands and inhabited by around 1.7 million people, mainly belonging to the Afar ethnic group (CSA, 2013). Their primary livelihood is a multi-species transhumant pastoralism formed over time so that residents can reside in a region with harsh, hostile conditions and limited natural resources (Schmidt \& Pearson, 2016). The Afar utilize complex herd management strategies, including breeding programs, culling, herd diversification, and controlled management of migration practices routes (Tesfay \& Tafere, 2004). This livelihood is currently threatened by numerous challenges such as worsening rangeland conditions due to over-grazing and land degradation, population growth (Sonneveld et al., 2010; Abule et al., 2005), changing property rights and sedentarization practices (Hundie \& Padmanabhan, 2008; Tsegaye et al., 2010), as well as increasing state interventions and modernization efforts (Makki, 2012; Schmidt \& Pearson, 2016).

Research was conducted in a semi-arid region at the foot of the Ethiopian Highlands at altitudes between 7701000 meters above sea level. Data were collected in four kebeles (lowest administrative unit in each district) in 
Ewa and Awra Woredas (district) (Figure 1) in order to identify potential differences between the different woreda and kebele governments. According to the latest official population numbers (CSA, 2013), Ewa has around 54,000 residents over 127,700 ha, a population density of 42 persons per square kilometre, while Awra $(309,600 \mathrm{ha})$ is less populated with an estimated 40,000 inhabitants or 13 persons per square kilometre (ANRS, $2011 a, b)$. Kebeles were selected with the cooperation of government and NGO officials working in the region according to the following criteria: different livelihood practices, i.e., those that had been classified by the government as either 'agro-pastoralist' or 'pastoralist', access to governmental and humanitarian aid, the presence of both formal and informal institutions and the perceived economic standing of the community. Using these selection criteria, four kebeles were chosen: Hida and Hiddalu in Awra, and 1st Batoli and Buti inEwa. For each kebele, the presence, relevance, and practices of indigenous and local institutions were documented.

\section{Sampling procedure and data collection methods}

Qualitative reflexive ethnographic fieldwork (Mauthner \& Doucet, 2003) was conducted in October/ November 2013 and in March 2014 to collect primary data. The period between 2013 and 2014 was used to analyse the initial data and to identify gaps and conflicting information. This time was also used to examine and contrast initial data with academic work and grey literature. Qualitative methods were selected since they allow interviewees to provide more detailed answers which can show how transitions impacted perceptions of local communities and how they could influence reactions to future changes. A qualitative approach provides greater depth to the reasoning behind the changing perceptions. Twenty seven in-depth semi-structured qualitative interviews were conducted with key informants (22 males, five females), with 14 participants interviewed multiple

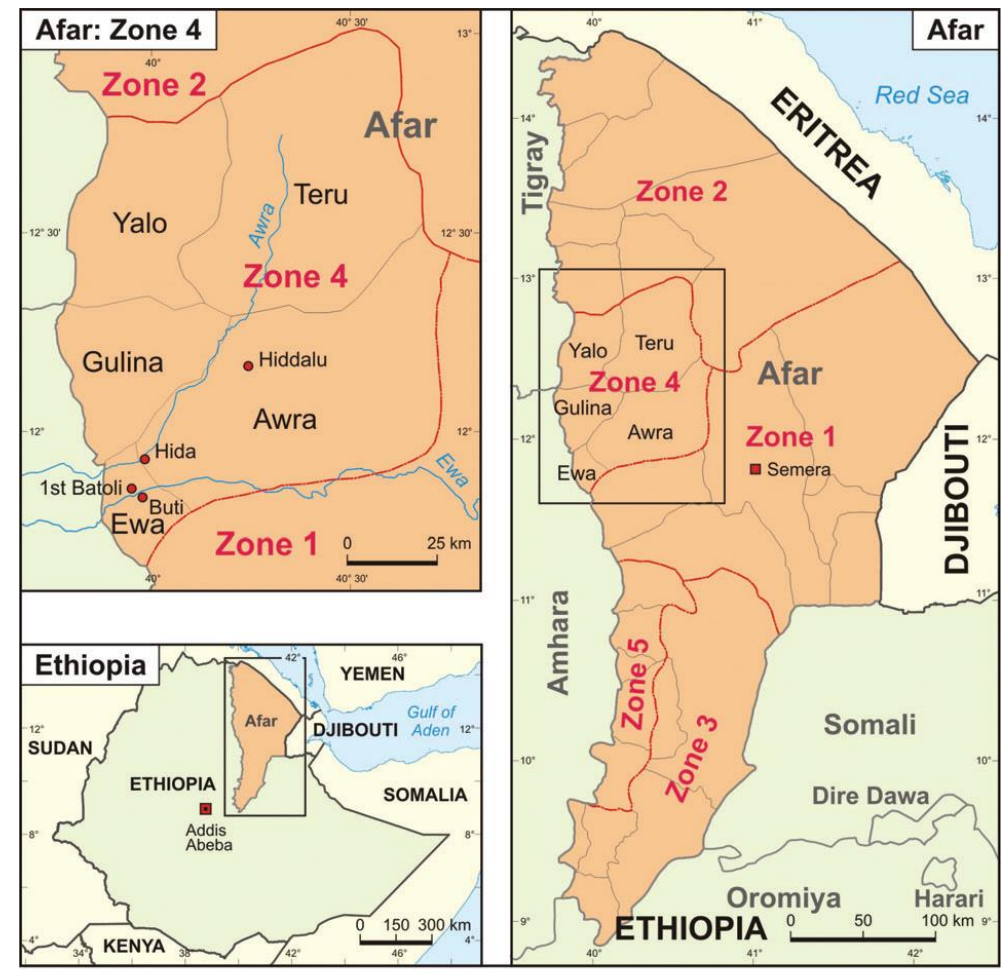

The representation of locations and boundaries should not be considered authoritative.Villages and borders were mapped using the researchers own data due to a lack of detailed official maps.

Figure 1. Location of the study area in Afar, Ethiopia.

Source: Prepared by Stephan Pohl, using data collected during fieldwork by Olivia Pearson.

times. Gender, age and occupation of the interviewees are listed in Figure 2. Initial interviews were carried out with clan and kebele leaders in order to gain access to the area with a second round of interviews being conducted with residents who were identified as potential key informants due to their position in the kebele (elders, committee members including those involved with natural resource management and farming cooperatives and local government officials including gender officers). The sampling selection was driven by the availability of participants and their willingness to engage in open discussions with the researchers as opposed to establishing specific targets for interviewee quotas. The increased presence of male interviewees is symptomatic of the patriarchal practices in the region, as females were reluctant to be interviewed when males were present. Therefore, informal techniques (conversations during social gatherings, meals, and at watering points) were utilized specifically to obtain the female perspective. 
Interviewees were asked to describe the current and past communication practices used to address, report, and solve problems, as well as the role and relevance of traditional and introduced institutions. Interviewees reflected on the different methods used when communicating with informal and formal institutional members, their strengths and weaknesses, and to what extent they felt that authorities listened to and worked towards resolving their demands and interests. Interviewees were asked to list (i) the regional and national development policies and strategies in their area, (ii) whether their concerns are respected and included once reported to institutional authorities and (iii) whether regional activities are relevant and/or meet (agro)-pastoralist demands and interests. Data were then cross checked through 20 semi-structured qualitative group interviews held in the focus kebeles with additional interviews conducted in neighbouring kebeles.

The formal institutional perspective is derived from 15 in-depth interviews and one focus group held in the field as well as in the cities of Semara, Logia, and Addis Ababa with officials from the Bureau of Pastoral and Agricultural Development (BoPAD) and the Water Department as well as with NGO employees. Diminished female representation, with only one of the 15 participants interviewed being female, was due to the predominately male staff at the selected departments and organizations. Interviewees reflected on the past and current role of their institution, its services and projects, and its geographical coverage. Participants were questioned about their knowledge of other regional institutions, both formal and informal, and their interaction with said institutions. Previous studies, relevant policies, legislation and reports pertaining to natural resource management and property rights in Afar were also reviewed. The unit of analysis for this paper is the kebele, with notable differences within the kebele referenced, e.g., gender based, formal or informal institutional management. Interviews were coded into groups which included the name, location, clan, age, gender, family status, occupation and economic standing of each interviewee. The dynamics and interactions that took place in each interview were questioned, taking into account other individuals present during the interview (e.g., husband or wife, government official), the interviewee's personal history, past and present government affiliations and economic standing. Coded groups were then analysed to identify the 'differences' (Lawson, 1995: 453), looking at how their background and current situation could have influenced differing opinions on the institutional changes in the region.

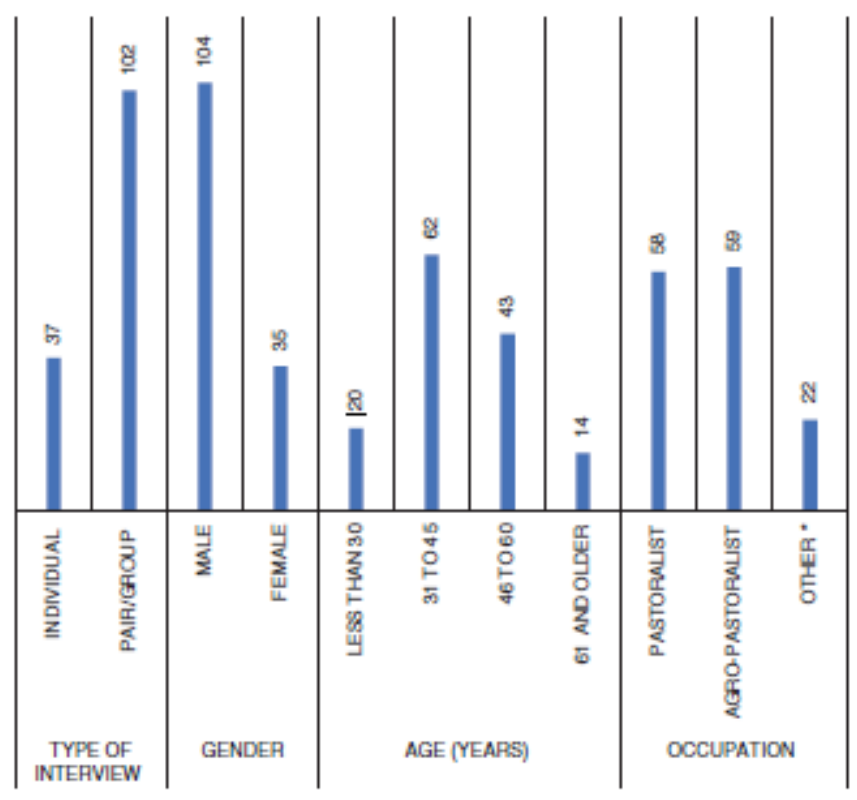

" GOVERMMENT AND NGO BMPLOYEES, AND CULTURML EXPERTS

Figure 2. Types of interviews and demographics of interviewees. Source: Pearson \& Schmidt, 2017.

\section{Conflicting institutions and governance in the Afar Region}

Traditional institutions, governance and representation practices in Afar Traditionally the Afar lands are divided into sultanates run by the Sultan (dardar), the religious and political leader of the clan (Stokes et al., 2009). Over a hundred clans (mela) are formed through patrilineal ancestral structures and affinal connections in each sultanate (Reda, 2011a). Clans are composed of related sub-clans (khida) which are groups of extended family units (dahla) (Markakis, 2011). Clans are divided between the Asaimara (the red/nobles) and the Adoimara (the white/commoners) (Lewis, 2017).

In Afar, the organization and governing of community concerns and needs are traditionally managed by the clan leader (makaban), sub-clan leaders (khida aba) and clan elders (Kassa, 2001). The male head of the household 
traditionally handles problems within families and households. However, if he is unable or unwilling to resolve a problem, additional male family members are brought in. Intra-clan concerns and conflicts are managed within the clan with residents, typically males, reporting their problems, demands, and interests to their clan or subclan leaders, depending on the nature of the issue and those involved. The leaders would then act as they saw fit and draw on the support of neighbours, relatives, and friends of the parties concerned in an attempt to mediate and prevent the issue from escalating (Sansculotte-Greenidge \& Fantaye, 2012). When the issue crossed sub-clan or clan borders and members of other clans and ethnic groups were involved, leaders from all affected groups were brought in. Problems that violated Afar customary law (ma'ada) were handled by an indigenous court (mablo) and resolved through negotiations, with compensation paid to those who were wronged (Reda, 2011b).

Other Afar institutions include the finaa, 'of equals', an informal institution made up of males of varying ages. The primary role of the finaa is to enforce the sanctions passed by clan authorities, including the confiscation of livestock or fines, and to maintain peace in the community. Members should be honourable men who believe and live by Afar ethics and cultural norms (Kassa, 1997). Other institutions utilize traditional reciprocal social security systems, the 'accrual of debts and obligations that can be recalled during crisis' (Davies \& Bennett, 2007: 496). They ensure that the weakest members of society receive support when needed, for example, after a household loses its herd due to drought, theft, or other unexpected setbacks. Clan and community members are required to donate when they are able to and, in turn, will call on others to donate when they require assistance. If community members do not comply, clan leaders are called in to impose sanctions. Commonly found forms include iribu, conducted within a sub-clan and close family network, and 'ala, a less formal agreement between unrelated Afar (Davies \& Bennett, 2007). Religion also plays an important role in social support networks. One of the key religious events is zakat, which occurs yearly and asks of wealthier members of society to donate a set percentage of their wealth. The percentage determined by the number of livestock found in each household. Donations are then distributed within the community.

\section{Governance changes in the Afar Region}

Significant institutional governance changes have occurred over the past three centuries altering formal and informal institutions as new administrations intertwined with and replaced the traditional. Historically the Afar have fought neighbouring ethnic groups and highland imperial agents both in defence of their rangelands and when invading and conquering neighbouring territories (Markakis, 2011; Yasin, 2008). During the turn of the 19th century, Emperor Menelik expanded Imperial Ethiopia using 'diplomacy, infiltration, or cohesion' (Shehim 1985: 332 ) to officially include the Afar Region and other periphery areas. However, the vast and (semi)-arid landscape meant that imperial agents had limited interactions with those who did not live along the base of the highland mountains (Markakis, 2011; Thesiger, 1935). The interactions which did occur, successfully removed several sultanates, leaving the Aussa Sultanate with its capital in Asaita as the primary functioning sultanate within Ethiopian borders (Puddu, 2016).

The attempted colonization by the fascist Italian government (1935-41) increased communications between the ruling Habasa leaders of the highlands with traditional periphery leaders of the Afar lowlands, such as the Aussa Sultanate of Afar. This was done to increase the control and influence that the Habasa had in the lowlands, and to form working relations by utilizing traditional structures (Puddu, 2016; Braukämper, 2013). Haile Selassie's absolutist state attempt to homogenize Ethiopia drove one of the most fundamental changes in Afar livelihoods; an instigation to transfer communal to private property through the introduction of plantations (cotton and sugarcane) along the Awash River and to promote private over communal land ownership (Abbay, 2004; Shehim, 1985).

The imperial government of Ethiopia was overthrown in 1974 by the military and socialist Derg Regime which strengthened governmental control and authority through the removal of customary ethnic practices (Abbink, 1997; Mengisteab, 1997). The present ruling party, the Ethiopian People's Revolutionary Democratic Front (EPRDF), came to power in 1991 and, unlike the previous two governing institutions, practiced ethno-regional federalism utilizing ethnic identity to gain and maintain control of the country (Samatar, 2004). The 1995 constitution created nine Regional States and two administrative districts, with regional boundaries following the distribution of the 80 various ethno-linguistic groups, and was designed to give each region a greater level of autonomy through decentralization (Abbink, 1997).

The EPRDF has created numerous formal institutions designed to address the pastoralist regions. Prominent examples include the Pastoralist Standing Affairs Committee with attendees being parliamentarians from areas primarily populated by pastoralists, several sedentarization programs that utilize groundwater and perennial rivers, the Sustainable Development and Poverty Reduction Program (SDPRP), the Five-Year (2000-2004) Development Plan which includes policies aimed at developing rural areas through strengthening agricultural strategies and implementing capacity building strategies, the subsequent Growth and Transformation Plan (2010/11- 
2014/15) as well as social protection interventions aimed at poverty reduction such as the Productive Safety Net Programme (PSNP) (Gilligan et al., 2009; Lister, 2004; FDRE 2010, 2002). Current governance practices have installed government representations at every political level-federal, regional, zonal, woreda, and kebele. This transition, the replacement of clan and traditional leaders by government officials, the interactions between woreda/ kebele leaders and community members, are the focal points of our paper.

\section{Results}

Community leadership and institutional management transitions

When discussing leadership at the community level, one of the key transitions has been the emergence of the kebele leader, a governmental position that has replaced the clan leader as leader of the community. All interviewees-both government officials and community members-recognize that the kebele leader must belong to and be a respected member of the community, and have a strong influence over the kebele: 'When they speak, others should listen. He should be able to sensitize and mobilize the community' (Government employee, pers. comm., Awra, 22 October 2013). This transition still leaves traditional leaders in a position of power, albeit with different roles. 'Before 1990 everything was done by the clan leader, but now by the kebele leader who uses the clan leader as an assistant' (Male pastoralist, pers. comm., Buti, 13 March 2014). The kebele leader's assigned duties include implementing federal and regional projects and distributing items given by the state, e.g., agricultural tools and products, as well as the allocation of aid, including food, water and health services.

Despite the changes to institutional governance, control and influence over the local population has not been completely driven from indigenous to governmental institutions and the divide between formal and indigenous management mirrors the divide between modern and traditional. The management of remaining traditional practices such as migration is initially facilitated and regulated through clan structures. Group interviews showed that pure pastoralists still prefer to move to areas where they have clan connections as it decreases conflict potential. Agro-pastoralists do not charge their clan members when allowing them into farming plots during the harvest season so that animals can feed off the unwanted produce (Pastoralists, pers. comm., Hida and Hiddalu, October 2013). Regardless of age or livelihood, interviewees agreed that conflicts that arise from this form of migration are managed locally while migration outside of Afar is dealt with by governmental agents. This sentiment was clarified during an interview conducted with the Head of the Ewa Peace Committee who advised that conflicts between different ethnic groups were the primary focus of government's conflict management (pers.comm, Ewa, 21 March 2014).

Informal institutional representations and practices help to integrate new formal institutions into the community by utilizing traditional techniques. A strong example of the mixing of traditional with formal is the 'Water Usage Management Committee', a committee created to maintain and control water usage. This type of committee is backed by the government and can take action against those who break their rules. However, these committees apply traditional laws and punishments to resolve the situation; problems are typically not brought before the government but rather, the community and committee. If the situation is beyond their control or management, then it is brought before the government. However, in Awra kebeles where these committees are in place, the regional government has not had to assist in solving any conflicts (Woreda Head, pers. comm, Awra, 20 October 2013).

\section{Transitioning institutional communication practices}

The introduced institutional governance practices stipulate that communication between residents and the regional government follows a precise chain, a chain understood by all participants. Community demands and interests are reported 'to one person, the kebele leader. Because he lives in my area he knows my problems' (Male pastoralist, pers. comm., Buti, 14 March 2014). Kebele leaders report to the woreda, woreda to regional government-and it is the Afar Regional Government that has the authority to take concerns to the federal bodies. 'All communication is done through the woreda: health, education, conflict, and agriculture. Once I went directly to the regional head to report hunger problems, but was sent back to the woreda and told to report to him' (Kebele Leader, pers. comm., Hiddalu, 17 March 2014).

Similarities between the formal and informal systems are present, a key being the leader's ability to measure the importance of issues and the appropriate solution. Traditional problem reporting and resolution processes allowed residents to participate but the ultimate decision was reserved for the clan leader(s), whose word was final. Those who 'wanted to take their problems into their own hands, [...] would have to deal with the clan leader who would punish them' (Agro-pastoralist, pers. comm., Hida, 19 March 2014). The change in institutional governance bestows this power on the kebele leader, who then 'decides what problem to take to the government. He decides what issues to address, what problems are important' (Clan Leader, pers. comm., Hiddalu, 16 March 2014). 


\section{Management of reported concerns and demands}

The increased communication between community members and their representatives, and the effectiveness of it resulted in a number of different perspectives. Younger residents and females were more likely to state that zero or insufficient solutions were provided for commonly reported problems. This subgroup stated that infrequent concerns such as intra-clan conflicts or problems within the household were resolved by kebele leaders. Reported concerns that remain unresolved include those that impact the whole community, centring on (i) a lack of water and food for humans and livestock and (ii) insufficient or missing health and veterinary supplies and services. 'Everything goes through the kebele leaders. They listen and act when conflicts happen. But not really for primary things, such as food or animal health' (Female pastoralist, pers. comm., Hiddalu, 29 October 2013). Older community members were more inclined to view this inability to successfully address and solve community concerns as not solely associated with the transition from informal to formal institutional governance. The changing natural and socio-economic conditions and the problems that accompany them also play a significant role. 'Ten years ago, I didn't need to speak to the leaders. I didn't have these problems' (Male pastoralist, pers. comm., Buti, 14 March 2014). They acknowledge the introduced systems, not based on their merit, but rather because they perceived that they did not and still do not have a choice in the matter. 'I think the laws are good, but they are not my laws. They are the laws of the government' (Male pastoralist, pers. comm., Hiddalu, 17 March 2014). Females were more likely to feel empowered by the change in reporting practices as they have enabled more women to voice their concerns directly to those who have the ability to act on them; kebele leaders. They see the new system as capable of reducing the gender imbalance by increasing the ability of females to report their problems directly to the kebele leader or gender officers, as opposed to going through their male relatives. 'Women can speak directly with the government and they get an answer. For example, if someone forces marriage, we can go to the kebele leader for help' (Female pastoralists, pers. comm., 1st Badoli, 15 March 2014). Spatiality is another important factor in communication specifically perceived in larger kebeles where residents at peripheral locations felt disadvantaged. A key concern

for residents is that for a problem to be solved, it must be reported repeatedly to the kebele leader. 'Only those who live close and repeatedly report their problems get help. People who live far away can't report every day so their problems are not answered' (Agro-pastoralist, pers. comm., 1st Badoli, 16 March 2014). In large and sparsely populated kebeles such as Hiddalu, those based far away from the kebele centre are clearly disadvantaged. The institutional perspective mirrors the community concerns when kebeles are situated further away from the woreda centres. Leaders who have to travel greater distances to speak with officials feel disadvantaged and believe that an inability to repeatedly report issues decreases the chances that the issues will be addressed.

\section{Awareness of policies and programs in the area}

After reviewing the program and policies in the area, awareness of them was used as indicator to gauge the topdown flow and comprehension of information from the regional and federal agencies and NGOs towards rural areas. Results showed that a difference exists between those in a position of power (government and traditional leaders) and community members.

Pastoralists and agro-pastoralists demonstrated limited awareness of the policies and programs that had been implemented in their area such as education programs, settlement projects, health (specifically anti-female genital mutilation) projects, and anticonflict regulations. The policies and programs that pastoralists were aware of were seen as beneficial, but only when fully implemented. 'Everything has a law, but the laws are not actioned' (Male pastoralist, pers. comm., Buti, 14 March 2014).

Knowledge and awareness of locally applicable policies differed between pastoralists and agro-pastoralists. Sedentarized Afar typically had a greater understanding of new and changing programs and policies compared to pure pastoralists, however their level of program and policy comprehension was minimal. Residents were typically unaware of the responsible stakeholder(s) implementing a specific project, be it the government, a donor, or the private sector. One governmental project referred to by all participants from all four kebeles is the sedentarization program, identifying it as one clearly owned and implemented by the government. Interviewees stated that kebele leaders are the gate keepers for project participation. The leaders of agro-pastoralist kebeles with sedentarization projects are responsible for allocating farming plots while those from pure pastoralist kebeles select participants for sedentarization schemes.

While prominent community members, such as clan and kebele leaders, were able to name and identify more projects and policies present in the region, their comprehension of these activities was limited and vague. Traditional leaders were also unconvinced that present programs and policies would be able to resolve what the local population sees as its major problems, i.e. a lack of water and food and worsening natural resource conditions. 
Yes, I know of the new laws. Laws for education, peace, to stop harming ladies. These laws are helpful for my soul, but not for eating, for sleeping. I think government programs are insufficient. We always ask the woreda for more, but get no answer. (Clan Leader, pers. comm., Awra, 19 March 2014)

An example of knowledge being restricted to government and quasi-government workers is the Productive Safety Net Programme (PSNP) which was cited by government employees and two agro-pastoralists who also worked for a local NGO but could not be identified by any other interviewees, even when prompted. While it would be expected that knowledge of locally applicable policies and programmes is proportionate to the individual's position on the information chain, it is also apparent that, at the grass-roots level, knowledge relates directly to the application of these policies to the gaining of day-to-day livelihood.

\section{Discussion}

\section{The aftermath of institutional change}

While the primary governance institution is now the formal government rather than clan based structures, government officials still recognize the important role of traditional leaders and elders in mediation and communication between clans and ethnic groups. The amalgamation of traditional and formal institutional management is also recognized by other studies-for example, Homann et al. (2008) analyse institutional rangeland management transitions in the Borana Region of Ethiopia. It is also documented in the management of grazing conflicts that smaller internal conflicts are more likely to be managed through clan structures while conflicts with bordering neighbouring ethnic groups are managed by formal institutions (Markakis, 2011). Tesfay and Tafere (2004) show that along the border between Afar and Tigray, a mutually established organizational system titled Gereb, composed of elders from Afar and Tigray, is used to enforce laws and bring about peace in bi-clan conflicts at monthly meetings. Yami et al. (2011) advocate providing policy and developmental support to informal institutions in Tigray that manage communal grazing lands as it could increase their capacities. In the Somali Region, elders collaborate with government officials, acting as peacemakers (Hagmann, 2007).

As shown, the repercussions of changes in governance institutions include opening the lines of communication by facilitating an increase in communication between women and their local officials. This opening increased the perception females had, that their problems and demands are being communicated, thus increasing the chance that they will be addressed. The opening of such institutional communication patterns is important due to the impact of increasing droughts and environmental deterioration in the region. Notably, 'poor and marginal populations whose livelihoods are primarily natural resource based' are heavily impacted by climate change (RodimaTaylor et al., 2012: 107), as are females due to the gender specific tasks connected with natural resource management (Denton, 2002). Stronger communication pathways that allow females to report concerns directly, strengthen the potential for direct interaction with the gender most affected by climate related changes (AroraJonsson, 2011; Goh, 2012). Recognizing and identifying the strengths and weaknesses in the changing communication patterns is also highly relevant in an area as susceptible to rapid environmental and socio-economic changes as the Afar Region where formal and informal institutions play an integral role in collecting and disseminating information. Based on our results, we have derived a number of recommendations that highlight the strengths and weaknesses on the aforementioned transitions. These recommendations may be employed to strengthen the implementation of future development programs and policies.

\section{Gendered communication paths}

Improved female communication paths could help to address an inbuilt gender inequality in formal property rights in Afar. Although males and females can both be awarded farming land, females are given less than males due to their perceived inability to maintain the same plot as men (Schmidt \& Pearson, 2016), hence females could benefit from better access to those with the ability to action their concerns and problems. Results found here may also be relevant in other pastoralist areas with increasingly settled agrarian populations, where improved gendered communication practices could help to tackle inequitable gender land ownership and access practices (Carr \& Thompson, 2014).

The opening of communication paths for women is also important in light of the increasing commodification of females in humanitarian and development work. This form of commodification is increasing due to the perceived connection between traditional gender roles and aid work, e.g., water collection for household purposes, females being more inclined to think of the future and put families first (Westermann et al., 2005). Thus, projects increasingly require a certain number of participants to be female in order to fill gender-based quotas, often using buzzwords such as empowerment to support this requirement. Stronger communication patterns with the female participants' development agencies will increase the understanding of the current needs of the population, as well as strengthen the understanding of the appropriate ways to engage with the different genders. What should not be forgotten is that the push for modernization in humanitarian and development work through the 
modernized woman can also result in gender commodification (Pearson \& Schmidt, 2017; O'Reilly, 2006) or the production of token female members in projects.

\section{Rural understanding of programs and policies}

The lack of rural understanding of new policies relevant to rural Afar inhibits implementation processes. Harnessing the strengths of and relationship between governmental and non-governmental institutions and their ability to communicate directly with rural residents can be incorporated into good governance designs (Cleaver et al., 2013). Project designs could be strengthened by drawing the focus towards how governance changes are perceived and implemented by both pastoralists and agro-pastoralists. This would highlight the relevant communication practices needed to reach both groups and the weaknesses described by each group. Additionally, as the Horn of Africa is recognized as having an increased vulnerability to drought (Gan et al., 2016), the need for timely and informed aid work is likely to increase.

An increased rural understanding of pertinent regional projects and policies, such as sedentarization and formal natural resource management, would strengthen implementation processes as participants would have a greater awareness of a project's relevance and its direct impact on their livelihoods. Rural members holding powerful positions are more likely to be aware of the most prevalent concerns and problems; however, if they are unable to speak with the relevant parties then the knowledge remains with them. Additional broadening and opening of communication channels would reduce the present limited information flow described earlier. Among those who live in the area, rural members with power are aware of the most prevalent concerns and problems. However, if they are unable to speak with the relevant parties, this awareness remains with them. Their understanding could be fed directly into project design or monitoring and evaluation to improve the relevance of future regional projects.

\section{Conclusion}

Institutional governance practices have transitioned in Afar through the introduction of the new and the restructuring of the old. Traditional, clan based institutions and leadership roles have been redirected and adapted to meet introduced formal government institutions. The traditional clan institutions that lacked de jure legitimacy are still functional, but their role and duties within society have changed. No longer are they the primary agents responsible for upholding traditional values and practices through the enforcement of cultural laws and the implementation of clan imposed sanctions. Instead, clan institutions now support government institutions and provide guidance to the new community leader; the kebele leader.

This paper argues that such shifts in institutional governance, from informal clan to formal government control, can be clearly documented when analysing the way rural Afar pastoralists, agro-pastoralists and local leaders communicate with each other. Problems are now predominately reported to and answered by kebele leaders rather than clan leaders and elders, with the clan providing assistance and guidance for control and management concerns. Some see this transition as a positive one, as it has opened up paths for groups who traditionally may not have been able to speak with leaders. Introduced communication practices now allow females to directly communicate with their local representatives, thus increasing the perception by female community members that their interests are heard.

Changes to institutional governance have transformed the flow of information, both from the community to institutional structures and vice versa. This means, however, that if the necessary community leaders are not involved or are misinformed, residents will remain uninformed about projects and programs relevant to their existence and livelihoods. This transition is relevant not only for the Afar, but also for the implementation of development programs and policies. As strong and effective formal and informal institutions are endorsed as tools that can assist and strengthen developing communities, a greater comprehension of changes to institutional control and management would improve policy design and program implementation in the focus area. This could be achieved by clarifying the tasks ascribed to each institution, how they are carried out and their effectiveness.

\section{Acknowledgements}

We would like to thank the Deutsche Gesellschaft für Internationale Entwicklung (GIZ) for their financial and logistical support. 


\section{References}

Abbay A (2004) Diversity and state-building in Ethiopia. African Affairs 103 (413), 593-614.

Abbink J (1997) Ethnicity and constitutionalism in contemporary Ethiopia. Journal of African Law 41 (2), 159-74.

Abule E, Snyman HA, Smit GN (2005) Comparisons of pastoralists' perceptions about rangeland resource utilisation in the middle Awash Valley of Ethiopia. Journal of Environmental Management $75,21-35$.

ANRS (Afar National Regional State) (2011a) Afar National Regional State Awra Technical Report: Land Degradation Assessment. ANRS, Semara.

ANRS (Afar National Regional State) (2011b) Afar National Regional State Ewa Technical Report: Land Degradation Assessment. ANRS, Semara.

Agrawal A (2010) Local institutions and adaptation to climate change. In Mearns R, Norton A (eds) The Social Dimensions of Climate Change: Equity and Vulnerability in a Warming World, 173-97. The World Bank Group, Washington, DC.

Agrawal A, Perrin N (2009) Climate adaptation, local institutions and rural livelihoods. In

Adger WN, Lorenzoni I, O'Brien KL (eds) Adapting to Climate Change: Thresholds, Values, Governance, 350-67. Cambridge University Press, New York.

Arora-Jonsson S (2011) Virtue and vulnerability: discourses on women, gender and climate change. Global Environmental Change 21 (2), 744-51.

Beyene AD, Koch SF (2013) Property rights, institutions and choice of fuelwood source in rural Ethiopia. Forest Policy and Economics 30, 30-38.

Braukämper U (2013) Indigenous views on the Italian occupation in Southern Ethiopia: a postcolonial approach. Aethiopica 14, 163-83.

Bush PD (1987) The theory of institutional change. Journal of Economic Issues 21 (3), 1075-116.

Carr ER, Thompson MC (2014) Gender and climate change adaptation in agrarian settings: current thinking, new directions, and research frontiers. Geography Compass 8 (3), 182-97.

Casson MC, Della Giusta M, Kambhampati US (2010) Formal and informal institutions and development. World Development 38 (2), 137-41.

Cleaver F (2002) Reinventing institutions: bricolage and the social embeddedness of natural resource management. The European Journal of Development Research 14 (2), 11-30.

Cleaver F, Franks T, Maganga F, Hall K (2013) Institutions, security, and pastoralism: exploring the limits of hybridity. African Studies Review 56 (3), 165-89.

CSA (Central Statistical Agency) (2013) Population Projection of Ethiopia for all Regions at Wereda Level from 2014-2017. CSA, Addis Ababa.

Davies J, Bennett R (2007) Livelihood adaptation to risk: Constraints and opportunities for pastoral development in Ethiopia's Afar region. Journal of Development Studies 43, 490-511.

Denton F (2002) Climate change vulnerability, impacts, and adaptation: why does gender matter? Gender \& Development 10 (2), 10-20.

Democratic Republic of Ethiopia (FDRE) (2002) Ethiopia: Sustainable Development and Poverty Reduction Program. Federal Ministry of Finance and Economic Development (MOFED), Addis Ababa.

Democratic Republic of Ethiopia (FDRE) (2010) Growth and Transformation Plan (2010/112014/15).

Federal Ministry of Finance and Economic Development (MOFED), Addis Ababa. 
Ensminger J (1997) Changing Property Rights: Reconciling Formal and Informal Rights to Land in Africa. In Drobak, JN, Nye JV (eds) The Frontiers of the New Institutional Economics, 165-96. Academic Press, San Diego

Gan TY, Ito M, Hülsmann S et al. (2016) Possible climate change/variability and human impacts, vulnerability of drought-prone regions, water resources and capacity building for Africa. Hydrological Sciences Journal 61 (7), 1209-26.

Gilligan D0, Hoddinott J, Taffesse AS (2009) The impact of Ethiopia's Productive Safety Net Programme and its linkages. The Journal of Development Studies 45 (10), 1684-706.

Goh AH (2012) A literature review of the gender-differentiated impacts of climate change on women's and men's assets and well-being in developing countries. CAPRi Working Paper No. 106. International Food Policy Research Institute, Washington DC. Institutional governance changes in Afar, Ethiopia 451

Hagmann T (2007) Bringing the Sultan back in: elders as peacemakers in Ethiopia's Somali Region. In Buur L, Kyed H (eds) State Recognition and Democratization in Sub-Saharan Africa: a New Dawn for Traditional Authorities? 31-51. Palgrave McMillan, New York.

Haller T, Fokou G, Mbeyale G, Meroka P (2013) How fit turns into misfit and back: institutional transformations of pastoral commons in African floodplains. Ecology and Society 18 (1), 34-49.

Harbeson JW (1978) Territorial and development politics in the Horn of Africa: the Afar of the Awash Valley. African Affairs 77 (309), 479-98.

Hinz MO (2007) Traditional governance and African customary law: Comparative observations from a Namibian perspective. In Bosl N, Horn A (eds) Human Rights and the Rule of Law in Namibia, 5987. Human Rights and Documentation Centre, Windhoek.

Homann S, Rischkowsky B, Steinbach J, Kirk M, Mathias E (2008) Towards endogenous livestock development: Borana pastoralists' responses to environmental and institutional changes. Human Ecology 36 (4), 503-20.

Hundie B, Padmanabhan M (2008) The Transformation of the Afar Commons in Ethiopia: State Coercion, Diversification, and Property Rights Change among Pastoralists. CAPRi Working Paper No. 87. International Food Policy Research Institute, Washington DC.

Kamara AB, Swallow B, Kirk M (2004) Policies, interventions and institutional change in pastoral resource management in Borana, southern Ethiopia. Development Policy Review 22 (4), 381-403.

Kamoche K, Qixun Siebers L, Mamman A, Newenham-Kahindi A (2015) The dynamics of managing people in the diverse cultural and institutional context of Africa. Personnel Review 44 (3), 330-45.

Kassa G (1997) A note on the Finaa (Fimaa) institution among the pastoral Afar of the Middle Awash Valley, North Eastern Ethiopia. Journal of Ethiopian Studies 30, 1-26.

Kassa G (2001) Resource conflicts among the Afar of North-East Ethiopia. In Salih M, Dietz T, Ahmed AG (eds) African Pastoralism: Conflict, Institutions and Government, 145-71. Pluto Press, London.

Lawson V (1995) The politics of difference: examining the quantitative/qualitative dualism in poststructuralist feminist research. The Professional Geographer 47 (4), 449-57.

Lesorogol CK (2003) Transforming institutions among pastoralists: inequality and land privatization. American Anthropologist 105 (3), 531-41.

Lewis IM (2017) Peoples of the Horn of Africa (Somali, Afar and Saho): North Eastern Africa, Part 1. Routledge, New York.

Lister S (2004) The processes and dynamics of pastoralist representation in Ethiopia. IDS Working Paper No. 220. Institute of Development Studies, Brighton.

Makki F (2012) Power and property: commercialization, enclosures, and the transformation of agrarian relations in Ethiopia. Journal of Peasant Studies 39, 81-104. 
Markakis J (2011) Ethiopia: The Last Two Frontiers. James Currey, London.

Mauthner N, Doucet A (2003) Reflexive accounts and accounts of reflexivity in qualitative data analysis. Sociology 37 (3), 413-31.

Mengisteab K (1997) New approaches to state building in Africa: the case of Ethiopia's ethnicbased federalism. African Studies Review 40 (3), 111-32.

Newenham-Kahindi A (2015) Managing sustainable development through people: implications for multinational enterprises in developing countries. Personnel Review 44 (3), 388-407.

North DC (1991) Institutions. The Journal of Economic Perspectives 5 (1), 79-112.

0’Reilly K (2006) 'Traditional' women, 'modern' water: linking gender and commodification in Rajasthan, India. Geoforum 37 (6), 958-72.

Pearson P, Schmidt M (2017) Commodity individuation of milk in the Somali Region, Ethiopia. Area. DOI: https://doi.org/10.1111/area.12359.

Puddu L (2016) State building, rural development, and the making of a frontier regime in Northeastern Ethiopia, c. 1944-75. The Journal of African History 57 (01), 93-113.

Reda KT (2011a) Social organization and cultural institutions of the Afar of Northern Ethiopia. International Journal of Sociology and Anthropology 3 (11), 423-29.

Reda KT (2011b) Conflict and alternative dispute resolution among the Afar pastoralists of Ethiopia. African Journal of History and Culture 3 (3), 39-47.

Renders M (2007) Appropriate 'governance-technology'? Somali clan elders and institutions in the making of the 'Republic of Somaliland'. Africa Spectrum 42 (3), 439-59.

Rodima-Taylor D, Olwig MF, Chhetri N (2012) Adaptation as innovation, innovation as adaptation: an institutional approach to climate change. Applied Geography 33, 107-11.

Samatar AI (2004) Ethiopian federalism: autonomy versus control in the Somali Region. Third World Quarterly 25 (6), 1131-54.

Sansculotte-Greenidge K, Fantaye D (2012) Traditional authority and modern hegemony: peacemaking in the Afar Region of Ethiopia. In Sansculotte-Greenidge K, Mutisi M (eds) Integrating Traditional and Modern Conflict Resolution: Experiences from Selected Cases in Eastern and the Horn of Africa. Africa Dialogue Monograph Series No. 2/2012.

Searle JR (2005) What is an institution? Journal of Institutional Economics 1 (1), 1-22.

Schmidt M (2012) Changing human-environment interrelations in Kyrgyzstan's walnut-fruit forests. Forests, Trees and Livelihoods 21 (4), 253-66.

Schmidt M, Pearson 0 (2016) Pastoral livelihoods under pressure: ecological, political and socioeconomic transitions in Afar (Ethiopia). Journal of Arid Environments 124, 22-30.

Shehim K (1985) Ethiopia, revolution, and the question of nationalities: the case of the Afar. The Journal of Modern African Studies 23 (2), 331-48.

Sonneveld BG, Pande S, Georgis K, Keyzer MA, Seid Ali A, Takele A (2010) Land degradation and overgrazing in the Afar Region, Ethiopia: a spatial analysis. In Zdruli P, Pagliai M, Kapur S, Faz

Cano A (eds) Land Degradation and Desertification: Assessment, Mitigation and Remediation, 97-110. Springer, Dordrecht.

Stokes J, Gorman A, Newman A (2009) Encyclopedia of the Peoples of Africa and the Middle East, 7-8. Infobase Publishing Inc, New York.

Tamanaha BZ (2015) The knowledge and policy limits of New Institutional Economics on development. Journal of Economic Issues 49 (1), 89-109.

Tesfay Y, Tafere K (2004) Indigenous rangeland resources and conflict management by the North Afar Pastoral Groups in Ethiopia. Dryland Coordination Group Report No. 31. DCG, Mekelle, Ethiopia. 
Thesiger W (1935) The Awash River and the Aussa Sultanate. The Geographical Journal 85 (1), 1-19.

Tsegaye D, Moe SR, Vedeld P, Aynekulu E (2010) Land-use/cover dynamics in Northern Afar rangelands, Ethiopia. Agriculture, Ecosystems and Environment 139, 174-80.

Turner MD (2011) The new pastoral development paradigm: engaging the realities of property institutions and livestock mobility in dryland Africa. Society and Natural Resources 24 (5), 469-84.

Unruh JD (2005) Changing conflict resolution institutions in the Ethiopian pastoral commons: the role of armed confrontation in rule-making. GeoJournal 64 (3), 225-37.

Upton C (2012) Adaptive capacity and institutional evolution in contemporary pastoral societies. Applied Geography 33, 135-41.

Van Allen J (1972) 'Sitting on a man': colonialism and the lost political institutions of Igbo women. Canadian Journal of African Studies 6 (2), 165-81.

Wakjira DT, Fischer A, Pinard MA (2013) Governance change and institutional adaptation: a case study from Harenna forest. Ethiopia Environmental Management 51 (4), 912-25.

Westermann 0, Ashby J, Pretty J (2005) Gender and social capital: the importance of gender differences for the maturity and effectiveness of natural resource management groups. World Development 33 (11), 1783-99.

Yami M, Vogl C, Hauser M (2011) Informal institutions as mechanisms to address challenges in communal grazing land management in Tigray, Ethiopia. International Journal of Sustainable Development \& World Ecology 18 (1), 78-87.

Yasin M (2008) Political history of the Afar in Ethiopia and Eritrea. Afrika Spectrum 42 (1), 39-65.

Young OR (2010) Institutional dynamics: resilience, vulnerability and adaptation in environmental and resource regimes. Global Environmental Change 20, 378-85. 